\title{
Spatiotemporal trends and drivers of fish condition in Chesapeake Bay
}

\author{
Robert J. Latour*, James Gartland, Christopher F. Bonzek \\ Virginia Institute of Marine Science, College of William \& Mary, Gloucester Point, Virginia 23062, USA
}

\begin{abstract}
Measures of condition in fishes are often used to assess the general well-being of fish populations since condition reflects the biotic and abiotic factors experienced by individuals over moderate time scales. Fish condition can also be used as an indicator of ecosystem suitability in the context of ecosystembased management. From an ecosystem perspective, evaluation of fish condition is best described over multiple spatiotemporal scales and in a multi-species context. This study analyzed $14 \mathrm{yr}(2002-2015)$ of fisheries-independent trawl survey data to evaluate trends in condition for 16 demersal fishes inhabiting Chesapeake Bay, the largest estuary in the USA. Seasonal and spatial variability in condition were inferred from linear mixed-effects models, while dynamic factor analysis (DFA) was used to reveal coherence among and drivers of annual trends in condition across all species and for 3 subgroups representing trophic guilds. Patterns of intra-annual condition varied among species, likely reflecting life history strategies and physiological responses to seasonal environmental conditions, while spatial patterns showed improved condition for both coastal and oligohaline species with increasing distance from their source. Annual trends in condition showed remarkable coherence for all fishes and for species within each trophic guild, suggesting that factors influencing condition-based indicators of ecosystem suitability operate at the community level. Spring mean surface chl a concentration was included in the selected DFA model for nearly all groups (exception: benthivores) and was statistically significant for several species, indicating the importance of bottom-up processes on bay-wide annual fish condition.
\end{abstract}

KEY WORDS: Fish condition - Bottom-up controls · Chesapeake Bay · Ecosystem-based management · Linear mixed effects models $\cdot$ LME $\cdot$ Dynamic factor analysis $\cdot$ DFA

${ }^{*}$ Corresponding author: latour@vims.edu

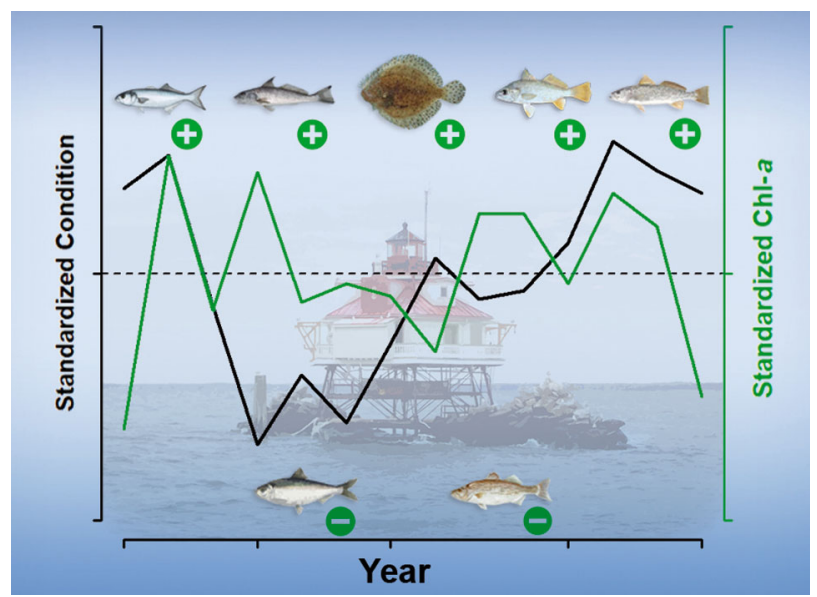

Chesapeake Bay fishes exhibited coherence to a common trend of annual condition. Correlations between condition and chl a suggest bottom-up forcing.

(Illustration: Melanie Chattin)

\section{INTRODUCTION}

Coastal estuaries are important ecosystems for a wide variety of marine organisms. The high primary and secondary production of estuaries combined with rich habitat diversity supports enhanced survival and foraging opportunities for fishes and invertebrates (Beck et al. 2001). For many species, the attributes of estuaries greatly aid transitions from juvenile to adult life stages, thereby facilitating production that underpins many derived ecosystem services (Pinto et al. 2014). However, persistent anthropogenic pressures and change have altered estuarine ecosystems to reflect reduced biodiversity and ecological stability (Jackson et al. 2001, Hooper et al. 2005, Lotze et al. 2006). Consensus has emerged

(C) The authors 2017. Open Access under Creative Commons by Attribution Licence. Use, distribution and reproduction are unrestricted. Authors and original publication must be credited. 
that maintenance and enhancement of aquatic ecosystem integrity, estuarine or otherwise, requires integrated operational frameworks that consider the dynamics of whole systems.

Measures of condition in fishes have been proposed as tools to assess and monitor the suitability of an ecosystem, since condition reflects a composite of the biotic and abiotic factors experienced by individuals over moderate time scales (Parrish \& Mallicoate 1995, Vila-Gispert \& Moreno-Amich 2001, Lloret et al. 2002). Fish condition is an indicator of the energy reserves of an animal, and at the population level, better condition is associated with increased rates of survival and reproductive success, as well as the ability to endure exploitation (Rätz \& Lloret 2003, Stevenson \& Woods 2006). Since higher-quality habitats generally yield higher condition, the latter can serve as a biotic proxy for ecosystem status. Several approaches have been developed to quantify fish condition, but the simple, morphometric Fulton's $k$ index (Fulton 1904, Le Cren 1951, Ricker 1975) is often considered related to fitness (Jakob et al. 1996). Despite utility as an ecosystem indicator for ecosystem-based management (Browman \& Stergiou 2004, Arkema et al. 2006, Curtin \& Prellezo 2010, Marshak et al. 2017), studies of fish condition have generally focused on a small number of species (Parrish \& Mallicoate 1995, Lloret et al. 2002) or short time periods (Vasconcelos et al. 2009), and very few have attempted to quantify exogenous drivers of variability in condition (Brosset et al. 2015a).

The Chesapeake Bay is the largest estuary in the United States and is among the largest in the world. It is a partially-mixed, relatively shallow, coastal plain estuary extending $320 \mathrm{~km}$ along its length and ranging from 6.4 to $91 \mathrm{~km}$ wide (Pritchard 1967, Day et al. 1989). Mean depth is $6.5 \mathrm{~m}$ (Kemp et al. 2005). Estuarine circulation is driven by freshwater inputs, which typically peak in spring and are supplied mainly by the northern and western tributaries, coupled with landward-flowing saltwater from the Atlantic. Water temperatures in the bay range from approximately $1-4^{\circ} \mathrm{C}$ in the winter to $28-30^{\circ} \mathrm{C}$ in the summer, and the combination of freshwater input and warm temperatures results in the development of a sharp pycnocline from late spring through early fall (Day et al. 1989). Given the broad intra-annual variability in these physical characteristics, diverse assemblages of boreal, temperate, and subtropical fishes utilize this estuary seasonally. Nearly $90 \%$ of the 267 fishes known to occur in the bay are transient (Murdy et al. 1997), and more than 50 of these species support commercial and recreational fisheries (Able \& Fahay 2010).
While the bay remains a highly productive ecosystem, anthropogenic activities beginning primarily in the late $19^{\text {th }}$ century have resulted in major changes to this estuary. Increased nutrient inputs due to population growth have led to eutrophication of the system which, in turn, has reduced water clarity, altered distribution and density of submerged aquatic vegetation, increased the spatial and temporal extent of hypoxic and anoxic events, and shifted the ecosystem from one dominated by benthic to one dominated by planktonic processes (Nixon 1995, Kemp et al. 2005). Watershed development has reduced available habitat and increased runoff and rates of sedimentation, particularly when land was cleared following European settlement (Brush 1989). Overfishing has resulted in massive reductions of some stocks, while others have collapsed and subsequently recovered (Rothschild et al. 1994, Richards \& Rago 1999, Wilberg et al. 2011). Although efforts to reverse some anthropogenic changes have begun to show signs of success, the bay is expected to continue experiencing physical, chemical, and biological changes in its structure and functioning as a result of changing climate (Najjar et al. 2010).

In this study, we analyzed time-series of condition for 16 seasonally abundant fishes inhabiting Chesapeake Bay using 14 yr of data collected by an extensive, multi-seasonal bottom trawl survey. We had 3 specific objectives: to (1) quantify spatial and seasonal variability in condition for these fishes, (2) evaluate the degree of coherence (if any) among interannual patterns in condition across these species from 2002 to 2015, and (3) investigate the relative importance of various covariates in explaining estimated annual time-series of fish condition. Collectively, our results support ongoing ecosystem-based management efforts for the Chesapeake Bay by evaluating community responses to ecosystem attributes and by serving as a baseline for monitoring responses of the bay to future agents of change.

\section{MATERIALS AND METHODS}

\section{Field and laboratory procedures}

Data for this study were obtained for the years 2002-2015 from the Chesapeake Bay Multispecies Monitoring and Assessment Program (ChesMMAP), which is a fisheries-independent bottom trawl survey that samples late-juvenile and adult fishes in the bay mainstem (3900 km² survey area). Research cruises are conducted during odd months from March to 
November with approximately 80 stations sampled per cruise (no sampling in Sep 2007 or Mar 2012). The survey follows a stratified random sampling design, with stratification of the mainstem based on latitude (5 regional strata) and depth (3 strata: 3.0-9.1, >9.1-15.2, and >15.2 mi Fig. 1). At each station, a 4-seam bottom trawl (13.7 m headline length, $15.2 \mathrm{~cm}$ stretch body mesh, $7.6 \mathrm{~cm}$ stretch cod end mesh) is towed with the current for $20 \mathrm{~min}$. Fishes collected from each survey tow are identified and enumerated. A randomly selected subsample of up to 5 fish per size-class (if multiple size-classes are collected, e.g. small, medium, large) is measured for length $(\mathrm{mm})$ and individual whole weight $(\mathrm{kg})$. Additional processing of each size-class is conducted for macroscopic sex determination and otolith-based aging for selected species. All protocols for sampling and euthanizing fish are approved by the College of William \& Mary's Institutional Animal Care and Use Committee (IACUC-2014-02-11-9290jxgart).

For laboratory-based age determination of selected species, the right sagittal otolith is mounted on a piece of 100 weight paper with a thin layer of Crystalbond. A transverse section is cut through the nucleus of the otolith, perpendicular to the sulcal groove, using 2 Buehler diamond wafering blades and a low speed Isomet saw. Blades are spaced to yield sections $0.4 \mathrm{~mm}$ thick, which are subsequently mounted onto glass slides using Crystalbond. Annuli are tabulated from each section using a microscope with transmitted light at $25 \times$ magnification. Final ages are assigned as the mode of annuli counts from 3 independent readers coupled with information on capture date relative to the timing of annual mark formation.

\section{Statistical analyses}

The following species were included for analysis because they were consistently sampled by the ChesMMAP survey (those with age data available are denoted with an asterisk): alewife Alosa pseudoharengus, Atlantic croaker* Micropogonias undulatus, bluefish* Pomatomus saltatrix, gizzard shad Dorosoma cepedianum, hogchoker Trinectes maculatus, kingfishes Menticirrhus spp., northern puffer Sphoeroides maculatus, northern searobin Prionotus carolinus, scup Stenotomus chrysops, silver perch Bairdiella chrysoura, spot* Leiostomus xanthurus, striped bass* Morone saxatilis, summer flounder* Paralichthys dentatus, weakfish* Cynoscion regalis,

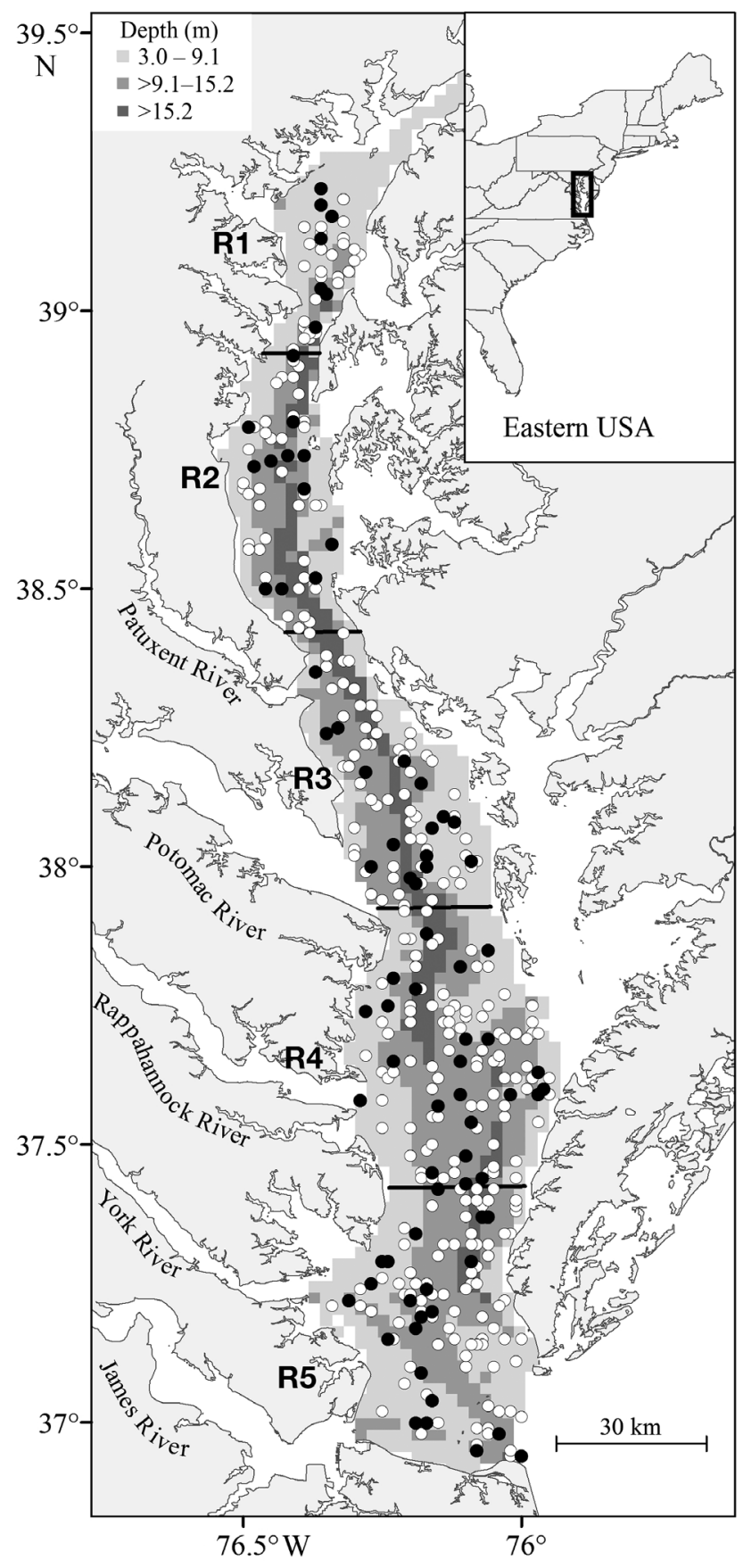

Fig. 1. Example of sampling locations (March 2015) for a cruise $(\bullet, \mathrm{n} \approx 80)$ and sampling coverage for a full year $(\mathrm{O}, \mathrm{n} \approx$ 400) for the Chesapeake Bay Multispecies Monitoring and Assessment Program. Horizontal lines delineate 5 regional strata; shading denotes the 3 depth strata

white perch* Morone americana, and windowpane flounder Scopthalmus aquosus.

Our analysis involved 3 steps: (1) calculation of Fulton's $k$ condition factor from the available survey data for each individual of the selected species, (2) estimation of a time-series of condition indices spanning 2002-2015 
for each species using modelbased procedures that incorporated effects of covariates synoptically measured during sampling, and (3) analysis of the condition time-series to extract any common trends amongst them and quantify the effects of annualized covariates at the community level. Four sets of taxonomic groupings were analyzed: all fishes (ALL), which comprised the 16 aforementioned species; benthivores (BENTH), which comprised Atlantic croaker, hogchoker, northern puffer, scup, spot, and white perch; piscivores (PISC), which comprised bluefish, striped bass, large summer flounder (>249 mm total length [TL]), and large weakfish $(\geq 100 \mathrm{~mm}$ fork length [FL]); and zooplanktivores (ZOOP), which comprised alewife, northern searobin, silver perch, small summer flounder ( $\leq 249 \mathrm{~mm} \mathrm{TL}$ ), and windowpane flounder. Analysis of the guild classifications beyond the ALL group was intended to explore similarities and/or differences in the common trends and covariates influencing fish condition across trophically defined components of the Chesapeake Bay fish community. The BENTH, PISC, and ZOOP groupings were based on guild classifications derived from analysis of $10 \mathrm{yr}$ of diet composition data collected by ChesMMAP (Buchheister $\&$ Latour 2015). Note that kingfishes are crustacivores and gizzard shad is a detritivore, so they were excluded from guild-specific groupings. Also, the sample size of small weakfish ( $<100 \mathrm{~mm}$ FL) did not permit estimation of annual condition values and could not be included in the ZOOP group.

Fulton's $k$ was calculated as:

$$
k_{i j}=10^{8} \cdot \frac{W_{i j}}{L_{i j}^{3}}
$$

where $i$ indexed individual fish within species/sizeclass $j$, the constant $10^{8}$ scaled the condition values to be close to 1.0, $w$ is total weight $(\mathrm{kg})$, and $L$ is either TL or FL (mm) depending on tail morphology. Each of the selected species/size-classes exhibits diverse life history strategies and thus different ontogenetic and spatiotemporal distributions within the Chesapeake Bay over the course of a year. Therefore, prior to generating time-series of annual condition for each species/size-class, the ChesMMAP data were filtered to exclude ages (when available), cruises, and bay regions with an average catch of $<5 \%$ of the total across years (Table 1).

Given a Fulton $k$ condition value for each fish from each survey tow in the filtered data set, linear mixed effects (LME) models were then applied to estimate species/size-class time-series of yearly condition. A suite of model parameterizations was considered to obtain the most parsimonious description of the condition data for each species/size-class, and Akaike's information criterion (AIC; Akaike 1973, Burnham \& Anderson 2002) was used to discriminate among competing model forms. All parameterizations included a fixed categorical year covariate and at least one of the following tow-level covariates: cruise, region, sex (all categorical), or age. For the species/ size-classes with available age data, 9 model forms were fitted in total, while for those without age information, 6 model structures were considered (Table S1 in the Supplement at www.int-res.com/ articles/suppl/m579p001_supp.pdf). To account for potential violation of the independence assumption caused by biological and ecological similarity of individuals collected at the same location (i.e. intra-haul correlation), station was treated as a random effect (Zuur et al. 2009). The general LME model structure was as follows: 


$$
\begin{aligned}
\mathbf{k}_{j}=\mathbf{X}_{j} \boldsymbol{\beta}_{j}+\mathbf{Z}_{j} \gamma_{j}+\varepsilon_{j} \text { where } \gamma_{j} \sim \mathrm{N}\left(0, \sigma_{\text {station }}^{2}\right) \\
\varepsilon_{j} \sim \mathrm{N}\left(0, \sigma^{2}\right)
\end{aligned}
$$

where $\mathbf{k}$ is the vector $(n \times 1)$ of Fulton's $k$ condition values for the $n$ individuals comprising species/sizeclass $j, \mathbf{X}$ is the design matrix $(n \times p)$ for $p$ fixedeffects, $\boldsymbol{\beta}$ is the vector $(p \times 1)$ of fixed-effect coefficients, $\mathbf{Z}$ is the design matrix $(n \times q)$ for $q$ random effects, $\boldsymbol{\gamma}$ is the vector $(q \times 1)$ of random effects (normally distributed with zero mean, variance $\sigma_{\text {station}}^{2}$ ), and $\boldsymbol{\varepsilon}(n \times 1)$ is the error vector (distributed normally with zero mean, variance $\sigma^{2}$ ). Fits of LME models were assessed through visual inspection of diagnostic plots (QQnorm and residuals) and by the magnitude of estimated marginal and conditional $\mathrm{R}^{2}$ values, which describe the proportion of variance in the data explained only by the fixed factors and by both fixed and random factors combined, respectively (Nakagawa \& Schielzeth 2013). Predicted yearly timeseries were generated from the model receiving the most empirical support using estimated marginal means (Searle et al. 1980).

Dynamic factor analysis (DFA) was then applied to estimate common trends among the time-series of yearly condition in each of the 4 species/size-class groupings and to investigate the importance of several annualized climatic and water quality covariates. DFA is a multivariate dimension reduction technique designed for relatively short, non-stationary time-series data. The goal of DFA is to identify a set of common underlying trends that explain temporal variation in a collection of time-series through a linear combination of hidden random walks. The general form of a DFA model can be written as follows (Zuur et al. 2003a,b, Holmes et al. 2014):

$$
\begin{aligned}
& \mathbf{k}_{t}=\boldsymbol{\Gamma} \boldsymbol{\alpha}_{t}+\mathbf{D} \mathbf{x}_{t}+\boldsymbol{\varepsilon}_{t} \text { where } \boldsymbol{\varepsilon}_{t} \sim \operatorname{MVN}(0, \mathbf{R}) \\
& \boldsymbol{\alpha}_{t}=\boldsymbol{\alpha}_{t-1}+\boldsymbol{\eta}_{t} \text { where } \eta_{t} \sim \operatorname{MVN}(0, \mathbf{Q})
\end{aligned}
$$

where $\mathbf{k}_{t}$ is the vector $(m \times 1)$ of estimated condition values for all $m$ species/size-classes in year $t_{1} \boldsymbol{\alpha}_{t}$ is the vector $(r \times 1)$ of $r$ common trends $(r<m), \Gamma$ is the matrix $(m \times r)$ of species-specific loadings on the trends, $\mathbf{x}_{t}$ is the vector $(q \times 1)$ of $q$ covariates, $\mathbf{D}$ is the matrix $(m \times q)$ of covariate effects, and $\mathbf{R}$ and $\mathbf{Q}$ denote the variance-covariance matrices associated with the observation error vector $\boldsymbol{\varepsilon}_{t}(m \times 1)$ and process error vector $\boldsymbol{\eta}_{t}(r \times 1)$, respectively, where both are assumed to follow a multivariate normal (MVN) probability distribution.

When applying DFA, it is important to identify the correct form of $\mathbf{R}$ since it specifies the variance and covariance structure among the $m$ time-series. Therefore, 3 structures of $\mathbf{R}$ were examined (Sta- chura et al. 2014): diagonal with equal variance and zero covariance, diagonal with unequal variance and zero covariance, and nondiagonal with equal variance and equal covariance. The diagonal matrix structures allow investigation of how similar the variability is across each of the time-series and whether or not that variability is best modeled as a single parameter or with multiple parameters. However, these structures assume that there are no relationships among time-series. In contrast, the nondiagonal structure allows the joint information among timeseries to be modeled. To ensure that model parameterizations were identifiable, $\mathbf{Q}$ was set to the identity matrix (Zuur et al. 2003a).

Ten annualized covariates were included in the DFA analysis, 4 of which were classified as climate variables, 4 were metrics of Chesapeake Bay water quality, and 2 were measures of available prey (polychaete density only applied to the BENTH group, and relative abundance of bay anchovy Anchoa mitchilli in the Virginia portion of Chesapeake Bay only applied to the PISC group). Climate covariates included the unsmoothed Atlantic Multidecadal Oscillation index $(\mathrm{AMO}$; www.esrl.noaa.gov/psd/data/ correlation/amon.us.data), the North Atlantic Oscillation (NAO; www.esrl.noaa.gov/psd/data/correlation/ nao.data), daily discharge $\left(\mathrm{m}^{3} \mathrm{~s}^{-1}\right)$ from the Susquehanna River (the bay's largest tributary, mean from February to May; http://waterdata.usgs.gov/usa/nwis/ uv? 01578310), and summer volume of hypoxic water (dissolved oxygen, DO $<2 \mathrm{mg} \mathrm{l}^{-1}$; D. Scavia pers. comm., University of Michigan). Water quality covariates included spring surface chl a concentration $(\mu \mathrm{g}$ $\mathrm{l}^{-1}$, mean from March to May predicted from a multiple linear regression model that included explanatory variables year, month, latitude, and longitude), bottom temperature $\left({ }^{\circ} \mathrm{C}\right.$, annual mean), bottom DO (mg $\mathrm{l}^{-1}$, annual mean), bottom salinity (PSU, annual mean). Data for the latter 4 covariates came from the Chesapeake Bay Program Water Quality Monitoring Program (http://data.chesapeakebay.net/WaterQuality), which is a state and federal partnership responsible for overseeing measurements of water quality parameters from fixed stations distributed throughout the tidal tributaries and mainstem of the bay. Samples are taken monthly during late fall and winter months and twice each month during warmer months. Prey covariates were polychaete (species list: www.baybenthos. versar.com/benthos/Species2005.htm\#polychaeta) density based on box core samples from bay tributaries and mainstem collected by the Chesapeake Bay Benthic Monitoring Program (www.baybenthos. versar.com/data.htm; $\mathrm{g}$ ash-free dry weight $\mathrm{cm}^{-2}$, 
mean from July to September predicted from a delta-lognormal generalized linear model that included the empirically supported combination of sample-level covariates year, month, and bay region as determined by AIC) and bay anchovy relative abundance estimated as weighted geometric means from data collected by the Virginia Institute of Marine Science (VIMS) Juvenile Fish and Blue Crab Trawl Survey (www.vims.edu/research/departments/fisheries/ programs/juvenile_surveys/data_products/indices/ bayanchovy/index.php). Prior to analysis with DFA, all covariate time-series were $z$-scored.

DFA models were structured to include 1 or 2 common trends for each of the $\mathbf{R}$ variance-covariance forms along with zero covariates (null models), a single climate, water quality, or prey (BENTH and PISC groups only) covariate, and 2 covariate parameterizations that included surface chl $a$ and bottom temperature. Model selection was achieved through the combined results of (1) AIC corrected for small sample size (AICc) for identifying empirically supported models (those with $\triangle \mathrm{AICc}<10$ were analyzed), (2) the ratio of sum-of-squared residuals and the sumof-squared observations (FitRatio $=\sum \hat{\varepsilon}_{t}^{2} / \sum \hat{k}_{t}^{2}$; smaller values indicate better model 'fit', Zuur et al. 2003b) for each species/size-class (individual species/sizeclass values and means across species/size-classes, denoted as 'Mean Fit'), and (3) visual evaluation of residuals plots and fits to observed time-series. Following the selection of the 'best' model, statistical significance for estimated factor loadings and covariate coefficients was inferred from $95 \%$ CI. All statistical analyses were performed using the $\mathrm{R}$ software program (v3.3.2, R Core Team 2016). Package 'Ime4' was accessed for fitting LMEs, and the package 'MARSS' was accessed for DFA.

\section{RESULTS}

\section{Fine-scale patterns in condition}

Fitted LME models were considered reliable for estimating yearly condition values from ChesMMAP data based on visual examinations of diagnostic plots. However, the model parameterization with the lowest AIC varied across species/size-class as did the goodness of fit (Table 2, Table S2 in the Supplement). Estimated marginal $\mathrm{R}^{2}$ values ranged from 8.7 (bluefish) to $32.9 \%$ (alewife) with an overall mean of $20.1 \%$ across species/size-classes, while estimated conditional $\mathrm{R}^{2}$ values ranged from 9.4 (bluefish) to $41.8 \%$ (alewife) with an overall mean of $31.4 \%$ (Table 2). The additional variation explained by including station as a random factor ranged from 0.7 to $21.0 \%$ and in proportion of the total from 7.5 to $51.5 \%$. For virtually all species/size-classes analyzed, such sizable gains in variation explained by just the random factor suggest considerable intraspecies clustering, such that variation in condition is much greater among samples than within samples. Estimated annual coefficients of variation (CV) associated with the yearly condition values were all less than 0.18 and indicative of good precision (Table 2).

Beyond the required year effect, all of the empirically supported LME models included the cruise fixed effect, which suggested appreciable seasonal variation in condition across species/size-classes. Relative to the earliest cruise of the year included for analysis, 4 species/size-classes showed consistent positive effects over the seasonal periods examined,

Table 2. Covariates included in the linear mixed effects (LME) models receiving the most empirical support, as identified using Akaike's information criterion (AIC), and used to estimate time-series of yearly condition. Covariates: $\mathrm{Y}-$ year, $\mathrm{C}-$ cruise, $\mathrm{R}-$ region, $\mathrm{A}$ - age, $\mathrm{S}$ - sex. Marginal $\mathrm{R}^{2}$ values provide information on the proportion of variance in the data explained by the fixed factors, while conditional $\mathrm{R}^{2}$ incorporates both fixed and random factors. The range of annual coefficients of variations (CV) associated with yearly condition values are provided for each species/size-class

\begin{tabular}{|lcccc|}
\hline Species & Covariates & $\begin{array}{c}\text { Marginal } \\
\mathrm{R}^{2}(\%)\end{array}$ & $\begin{array}{c}\text { Conditional } \\
\mathrm{R}^{2}(\%)\end{array}$ & CV range \\
\hline Alewife & Y+C+S & 32.9 & 41.8 & $0.06-0.16$ \\
Atlantic croaker & $\mathrm{Y}+\mathrm{C}+\mathrm{R}+\mathrm{A}+\mathrm{S}$ & 18.6 & 30.2 & $0.03-0.04$ \\
Bluefish & $\mathrm{Y}+\mathrm{C}+\mathrm{R}+\mathrm{A}$ & 8.7 & 9.4 & $0.03-0.05$ \\
Gizzard shad & $\mathrm{Y}+\mathrm{C}+\mathrm{R}$ & 14.3 & 25.6 & $0.05-0.07$ \\
Hogghoker & $\mathrm{Y}+\mathrm{C}+\mathrm{R}+\mathrm{S}$ & 20.5 & 32.1 & $0.07-0.11$ \\
Kingfishes & $\mathrm{Y}+\mathrm{C}+\mathrm{R}+\mathrm{S}$ & 10.6 & 19.9 & $0.04-0.05$ \\
Northern puffer & $\mathrm{Y}+\mathrm{C}$ & 23.6 & 32.2 & $0.06-0.07$ \\
Northern searobin & $\mathrm{Y}+\mathrm{C}$ & 24.2 & 37.7 & $0.09-0.18$ \\
Scup & $\mathrm{Y}+\mathrm{C}$ & 19.0 & 29.0 & $0.06-0.07$ \\
Silver perch & $\mathrm{Y}+\mathrm{C}+\mathrm{R}$ & 20.0 & 25.2 & $0.05-0.09$ \\
Spot & $\mathrm{Y}+\mathrm{C}+\mathrm{R}+\mathrm{A}$ & 23.1 & 39.6 & $0.06-0.07$ \\
Striped bass & $\mathrm{Y}+\mathrm{C}+\mathrm{A}+\mathrm{S}$ & 19.8 & 40.8 & $0.05-0.06$ \\
Summer flounder (all sizes) & $\mathrm{Y}+\mathrm{C}+\mathrm{R}+\mathrm{A}+\mathrm{S}$ & 31.1 & 41.4 & $0.03-0.04$ \\
Summer flounder (small) & $\mathrm{Y}+\mathrm{C}+\mathrm{A}$ & 17.8 & 28.1 & $0.03-0.04$ \\
Summer flounder (large) & $\mathrm{Y}+\mathrm{C}+\mathrm{R}+\mathrm{A}+\mathrm{S}$ & 29.0 & 38.9 & $0.03-0.04$ \\
Weakfish (all sizes) & $\mathrm{Y}+\mathrm{C}+\mathrm{R}$ & 15.7 & 29.5 & $0.05-0.06$ \\
Weakfish (large) & $\mathrm{Y}+\mathrm{C}+\mathrm{R}$ & 16.1 & 31.3 & $0.05-0.06$ \\
White perch & $\mathrm{Y}+\mathrm{C}+\mathrm{R}+\mathrm{A}+\mathrm{S}$ & 19.2 & 36.6 & $0.06-0.07$ \\
Windowpane flounder & $\mathrm{Y}+\mathrm{C}+\mathrm{R}+\mathrm{S}$ & 16.7 & 26.7 & $0.05-0.07$ \\
& & & & \\
\hline
\end{tabular}


(a)

\begin{tabular}{c|c|c|c|l|l}
\hline 0 & & & & -0.06 & Alewife \\
\hline 0 & 0.09 & 0.07 & 0.15 & 0.15 & Atl. croaker \\
\hline & 0 & -0.07 & -0.04 & 0.03 & Bluefish \\
\hline 0 & 0.04 & -0.07 & -0.01 & 0.09 & G. shad \\
0 & 0.16 & 0.04 & -0.12 & 0.07 & Hogchoker \\
& 0 & -0.03 & -0.02 & -0.001 & Kingfishes \\
& 0 & -0.23 & 0.01 & 0.33 & N. puffer \\
& & 0 & -0.14 & 0.02 & N. searobin \\
& 0 & 0.1 & 0.32 & 0.35 & Scup \\
& 0 & -0.07 & -0.18 & -0.09 & S. perch \\
\hline 0 & 0 & 0.08 & 0.08 & 0.04 & Spot \\
0 & 0.01 & -0.08 & -0.18 & -0.09 & S. bass \\
0 & & 0.01 & 0.03 & 0.05 & S. flounder \\
0 & 0.01 & -0.01 & -0.02 & 0.003 & S. flounder (sm) \\
& 0 & -0.04 & -0.02 & 0.04 & S. flounder (lg) \\
& 0 & -0.04 & -0.02 & 0.07 & Weakfish \\
\hline 0 & -0.03 & -0.1 & -0.2 & -0.11 & Weakfish (lg) \\
\hline 0 & -0.06 & -0.02 & -0.09 & -0.09 & Windowpane \\
\hline Mar & May & Jul & Sep & Nov &
\end{tabular}

(c)

\begin{tabular}{|l|l|}
\hline 0.01 & Atl. croaker \\
\hline 0.05 & Bluefish \\
\hline 0.12 & Spot \\
\hline 0.01 & S. bass \\
\hline 0.03 & S. flounder \\
\hline-0.04 & S. flounder (sm) \\
\hline 0.03 & S. flounder (lg) \\
\hline 0.01 & W. perch \\
\hline Age & \\
\hline
\end{tabular}

(b)

\begin{tabular}{|c|c|c|c|c|l|}
\hline & 0 & -0.09 & -0.1 & -0.13 & Atl. croaker \\
\hline 0 & -0.06 & -0.06 & -0.14 & -0.14 & $\begin{array}{l}\text { Bluefish } \\
\text { G. shad }\end{array}$ \\
\hline 0 & 0.06 & & & & Hogchoker \\
\hline 0 & & -0.03 & -0.12 & -0.004 & Kingfishes \\
& & & 0 & 0.03 & K. perch \\
\hline 0 & 0 & & -0.2 & -0.2 & S. \\
& -0.1 & -0.14 & -0.13 & -0.14 & Spot \\
& & 0 & -0.03 & -0.04 & S. flounder \\
& & 0 & -0.03 & -0.04 & S. flounder (lg) \\
& & 0 & -0.02 & -0.03 & Weakfish \\
\hline 0 & 0.03 & 0.09 & -0.02 & -0.04 & Weakfish (Ig) \\
& & & 0 & 0.05 & Windowpane \\
\hline R1 & R2 & R3 & R4 & R5 & \\
\hline
\end{tabular}

(d)

\begin{tabular}{|c|c|l|}
\hline 0 & -0.08 & Alewife \\
\hline 0 & -0.02 & Atl. croaker \\
0 & -0.09 & Hogchoker \\
0 & -0.04 & Kingfishes \\
0 & 0.01 & Striped bass \\
0 & -0.01 & S. flounder \\
0 & -0.01 & S. flounder $(\mathrm{lg})$ \\
0 & -0.06 & W. perch \\
\hline 0 & -0.05 & Windowpane \\
\hline Female & Male & \\
\hline
\end{tabular}

Fig. 2. Estimated coefficients associated with the fixed-effect covariates (a) cruise (month), (b) region (R1-R5, see Fig. 1), (c) age, and (d) sex included in the most parsimonious linear mixed effects model for each species/size-class. Coefficients are given for each level of the categorical covariates (i.e. cruise, region, and sex). Red tones: increasing trends; purple tones: decreasing trends. Blank cells indicate no observations for a given level of a covariate due to data filtering. See Table 1 for full species names

5 showed consistently negative effects, and 10 exhibited declining condition from late winter/spring through summer, followed by an increase from those minima with the onset of fall. (Fig. 2a). The most notable decreases in condition with season were for white perch and windowpane flounder, while scup, Atlantic croaker, and spot showed the largest increases in seasonal condition. For those species with mixed seasonal effects, northern puffer, hogchoker, and gizzard shad exhibited the largest negative to positive shifts over the summer-fall transition. Striped bass showed a very slight increase in spring condition followed by a notable summer minimum.

The region covariate was included in LME models for 13 of $19(68.4 \%)$ species/size-classes, which suggested considerable spatial variation in condition. Relative to the northernmost region included for analysis, 9 species/size-classes $(69.2 \%)$ exhibited consistently negative effects along the north-to-south axis of the bay mainstem, while $4(30.8 \%)$ displayed positive effects (Fig. 2b). The most pronounced regional declines in condition were for silver perch, bluefish, and spot, while white perch and gizzard shad showed the highest positive spatial effects.

Out of the 10 species/size-classes with available age data, the LME model with the lowest AIC contained the age covariate for $8(80 \%)$ species/size-classes, and all of the estimated effects were positive except for small summer flounder, which only included age 0-1 individuals (Fig. 2c). Spot and bluefish displayed the largest age effects; however, the magnitude of all of the age effects was fairly low.

The sex covariate was included in the most supported LME model for 9 (47.4\%) species/size-classes, and negative effects in condition were estimated for all males relative to females except in striped bass 
(Fig. 2d). Hogchoker and alewife showed the largest differences, while summer flounder (size classes: all sizes and large) exhibited the smallest differences. As with the age effects, the magnitude of all sex effects was low.

\section{Broad-scale patterns in condition}

Patterns in the 10 annualized covariates were variable across time (Fig. 3). The AMO and NAO showed approximately opposite patterns between 2002 and 2015, while trends in Susquehanna River mean daily discharge and summer volume of hypoxic water were similar and peaked in 2011 (Fig. 3a). Surface chl a concentrations were variable between low points in 2002 and 2015 (Fig. 3b). Mean annual bottom temperatures were highest and lowest in 2012 and 2003, respectively (Fig. 3b). The pattern of mean bottom dissolved oxygen concentration showed a parabolic shape, while mean bottom salinity was below average between 2003 and 2005, and again in 2011 and 2014 (Fig. 3b). Benthic polychaete density declined between 2002 and 2006, and then exhibited an increasing trend to a time-series high in 2015, while bay anchovy relative abundance in the Virginia portion of Chesapeake Bay increased between 2002 and 2010 and decreased thereafter (Fig. 3c).

The DFA models fitted the yearly time-series of mean Fulton's $k$ condition well for each taxonomic grouping. Specific to the ALL group, the selected model for inference contained a single common trend, the spring chl a covariate, and a diagonal with equal variance and zero covariance $\mathbf{R}$ matrix structure (Table S3 in the Supplement). Although the selected model did not yield the lowest AICc value, it provided a much lower Mean Fit value indicative of markedly improved fits to each time-series when compared to more AICc supported parameterizations. The estimated common trend indicated that condition was relatively high during the early 2000s, low during the mid-2000s, and increasing to the time-series peak thereafter (Fig. 4a). Remarkably, estimated factor loadings for all species on the common trend were positive (Fig. 4b), and species-specific fits to the condition time-series were all generally good (Fig. 4c). Species with the smaller estimated FitRatios (range: 0.17-0.32) and better overall model fits were weakfish, spot, and northern puffer, while species with the larger FitRatios (range: 0.61-0.74) and poorer model fits were gizzard shad, northern searobin, and striped bass. All factor loadings were statistically significant except for bluefish
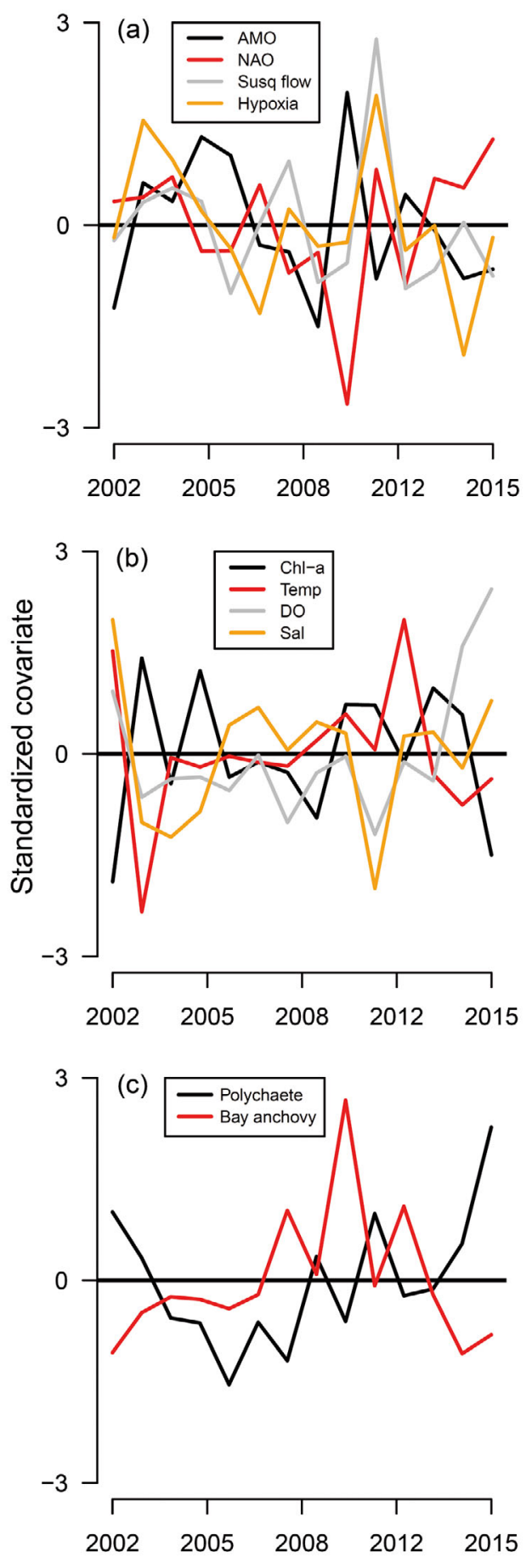

Fig. 3. Time-series of standardized covariates included in the dynamic factor analysis (DFA) of annual mean condition of Chesapeake Bay fishes. (a) Climatic variables (unsmoothed Atlantic Multidecadal Oscillation [AMO], the North Atlantic Oscillation [NAO] index, Susquehanna River discharge, and summer volume of hypoxic water), (b) water quality (spring surface chl a concentration, bottom water temperature, bottom dissolved oxygen concentration, and bottom salinity), and (c) measures of prey availability (baywide benthic polychaete density and bay anchovy relative abundance in the Virginia portion of Chesapeake Bay) 


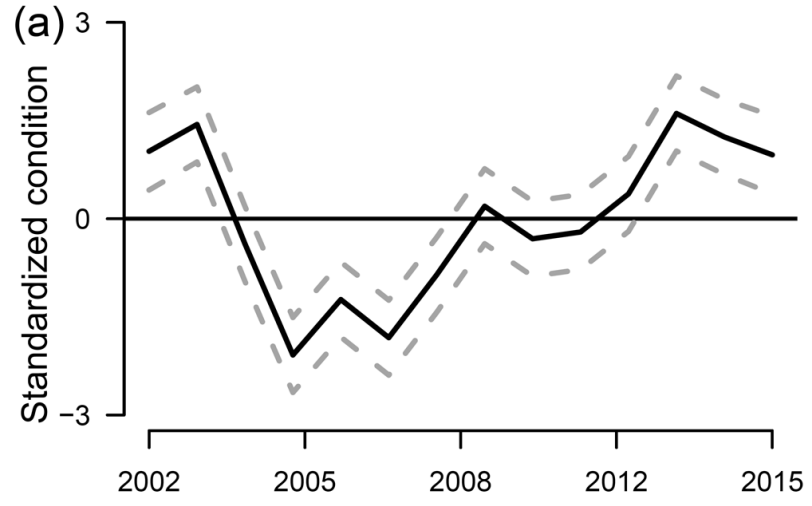

(c)

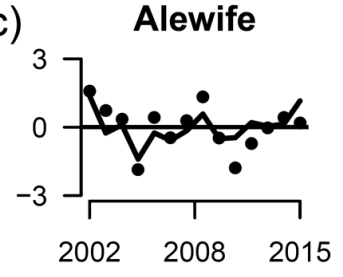

Hogchoker

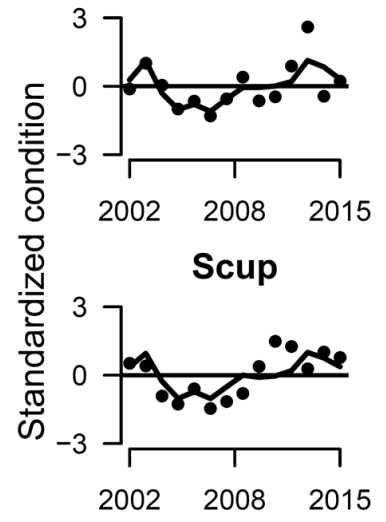

S. flounder

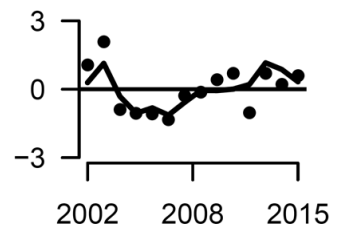

A. croaker

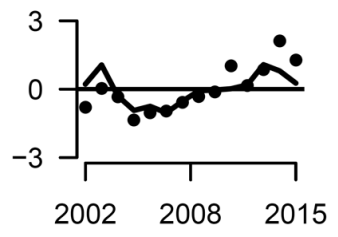

Kingfishes

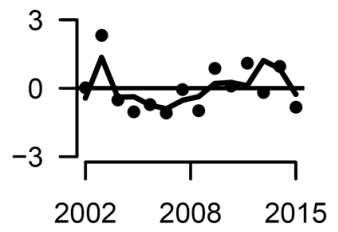

S. perch

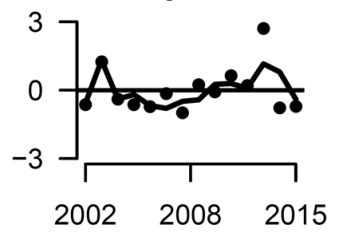

Weakfish

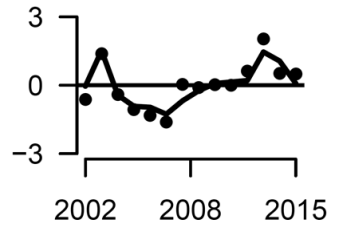

(b)

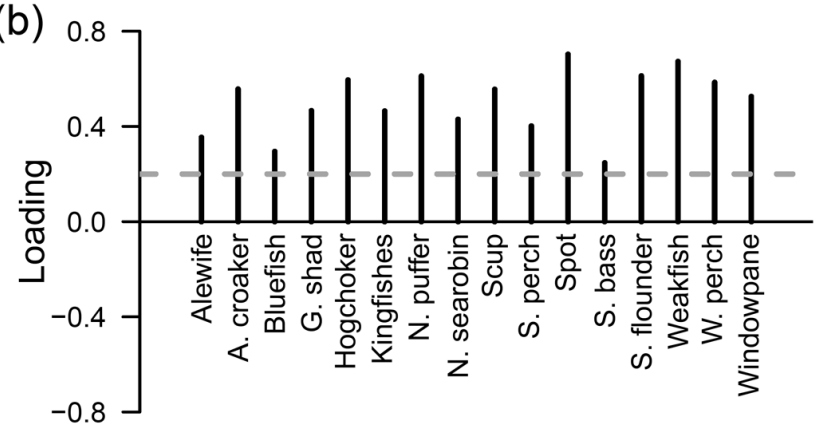

Bluefish

G. shad

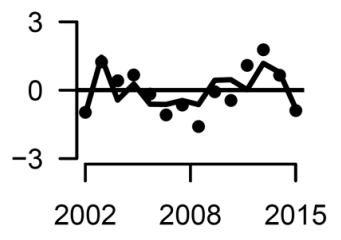

N. puffer

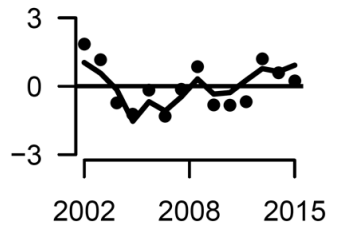

Spot

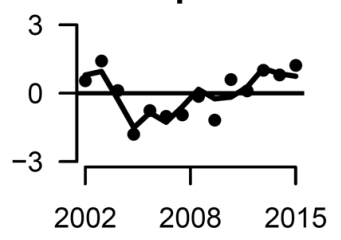

W. perch

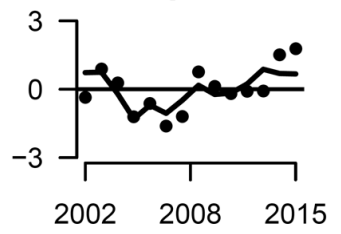

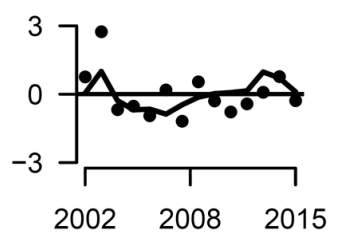

N. searobin

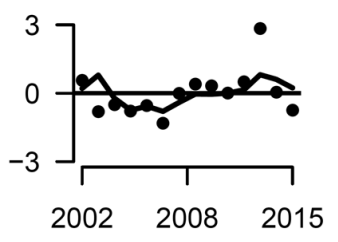

S. bass

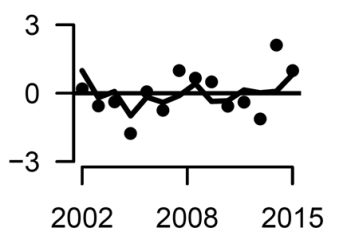

Windowpane

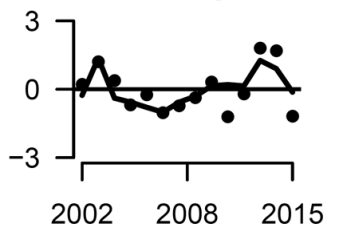

Fig. 4. (a) Estimated common trend (solid line) and 95\% CI (dashed lines) generated from dynamic factor analysis (DFA) using estimated annual mean condition values derived from linear mixed effect models for 16 fishes (ALL) inhabiting Chesapeake Bay. (b) Factor loadings for each species; loadings greater than 0.2 (horizontal dashed line) identify time-series of condition that had a relatively strong influence on the common trend. (c) Fits to the condition time-series for each of the species included

in the ALL DFA. See Table 1 for full species names

and striped bass, although both estimates exceeded the 0.2 cutoff (Zuur et al. 2003b) and were nearly significant (bluefish $95 \%$ lower confidence limit [LCL]: -0.03 , striped bass $95 \%$ LCL: -0.08 ; Table S4 in the Supplement). Statistically significant negative effects of the chl a covariate were detected for alewife and striped bass, while significant positive effects were estimated for bluefish, kingfishes, silver perch, and windowpane flounder. Near significance was detected for the estimated positive chl a effect for weakfish (95\% LCL: -0.04; Table S4).

The selected DFA model for the BENTH group included a single common trend, no covariates, and an $\mathbf{R}$ matrix structure that was diagonal with equal vari- 
ances and zero covariance (Table S3). This model had the lowest AICc and an intermediate Mean Fit value. Those models with lower Mean Fit values yielded very similar common trends to the selected model and thus were not retained based on parsimony. Intermediate AICc and Mean Fit values were associated with the model that included the polychaete density covariate, which suggested some empirical support for effects of benthic prey resources on mean annual condition. The estimated common trend from the selected model for the BENTH group showed a very similar pattern to that of the ALL group, although the increase in condition to the time-series peak in recent years was less variable (Fig. 5a). Factor loadings on the single common trend were again all positive and statistically significant (Fig. 5b, Table S4). Good species-specific fits to the condition time-series and low FitRatios (range: 0.17-0.33) were achieved for spot, Atlantic croaker, and scup, while the poorest fit and largest FitRatio (0.64) was for northern puffer (Fig. 5c).
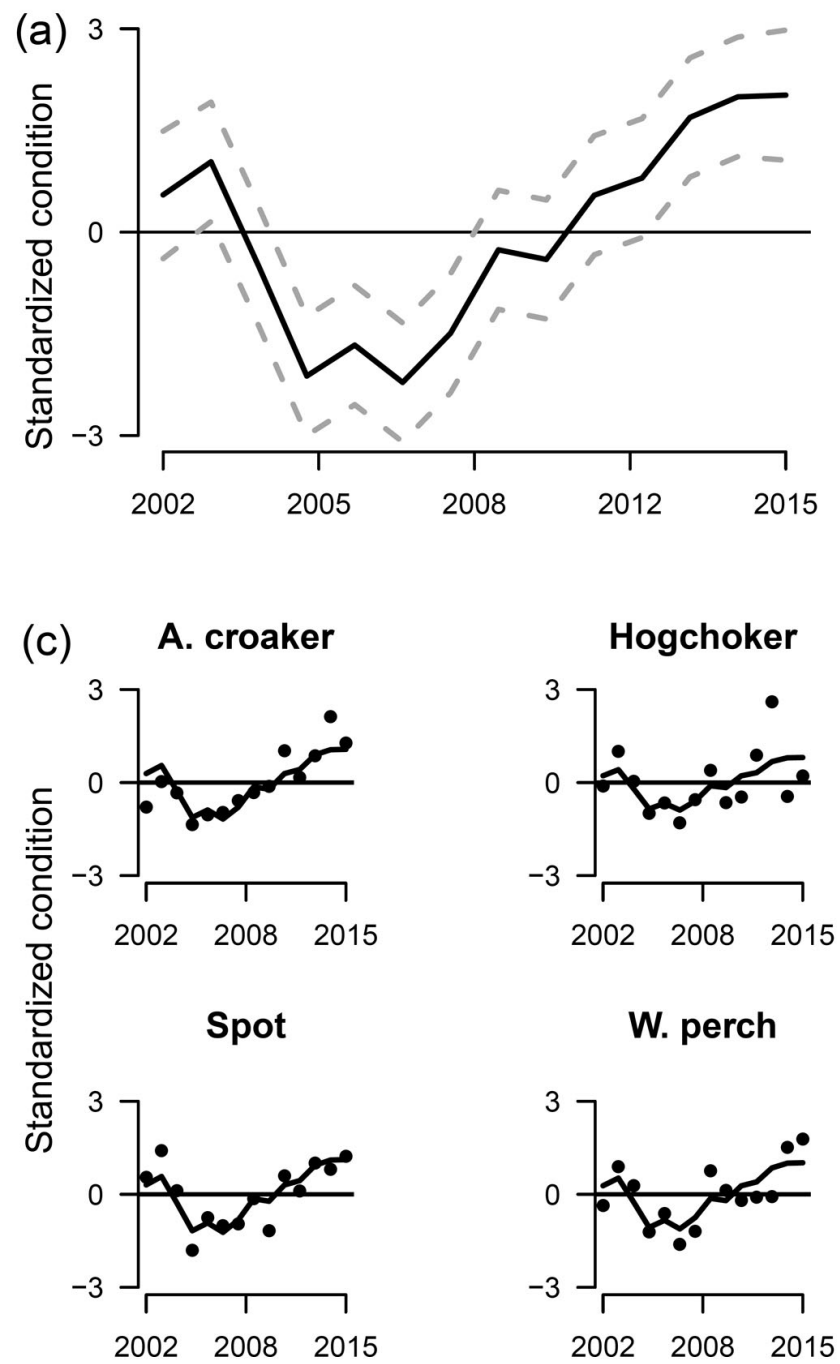

For the PISC group, the selected DFA model structure included one common trend, the spring chl a covariate, and a diagonal and unequal variance $\mathbf{R}$ structure and zero covariance. The top 3 AICc-supported models all contained the chl a covariate but different $\mathbf{R}$ structures, so the model with the lowest Mean Fit was selected (Table S3). The common trend across years was similar to, but more variable than those from the ALL and BENTH groups (Fig. 6a), and although all species/size-class factor loadings were positive, only those for large summer flounder and large weakfish were statistically significant (Fig. 6b). Low FitRatios (range: 0.08-0.34) and good fits to the condition time-series were associated with bluefish, large summer flounder, and large weakfish, while the large FitRatio (0.79) of striped bass signified a much poorer fit (Fig. 6c). The estimated coefficients of the chl a covariate were positive for all species/ size-classes except striped bass. Statistical significance was detected for bluefish, and near signifi-

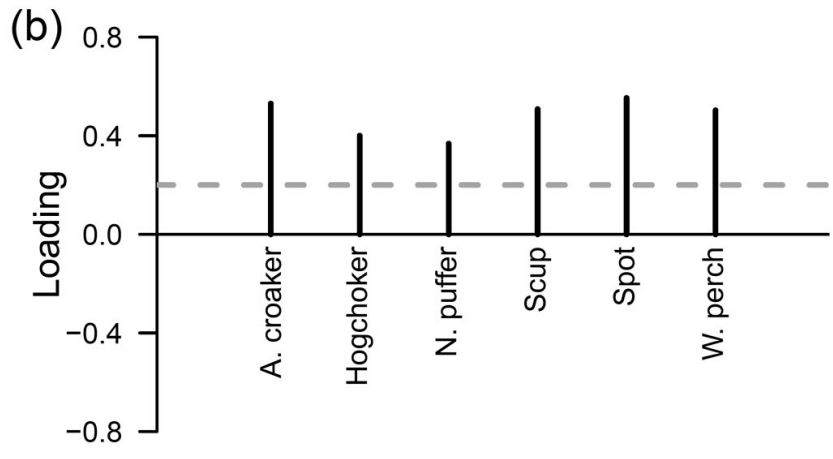

N. puffer

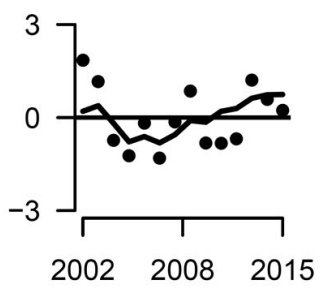

Scup

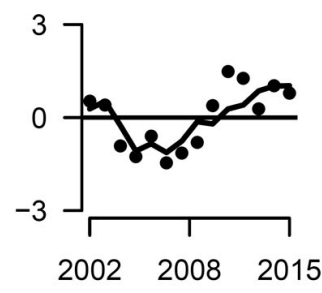

Fig. 5. As in Fig. 4 but for 6 benthivores (BENTH) inhabiting Chesapeake Bay 

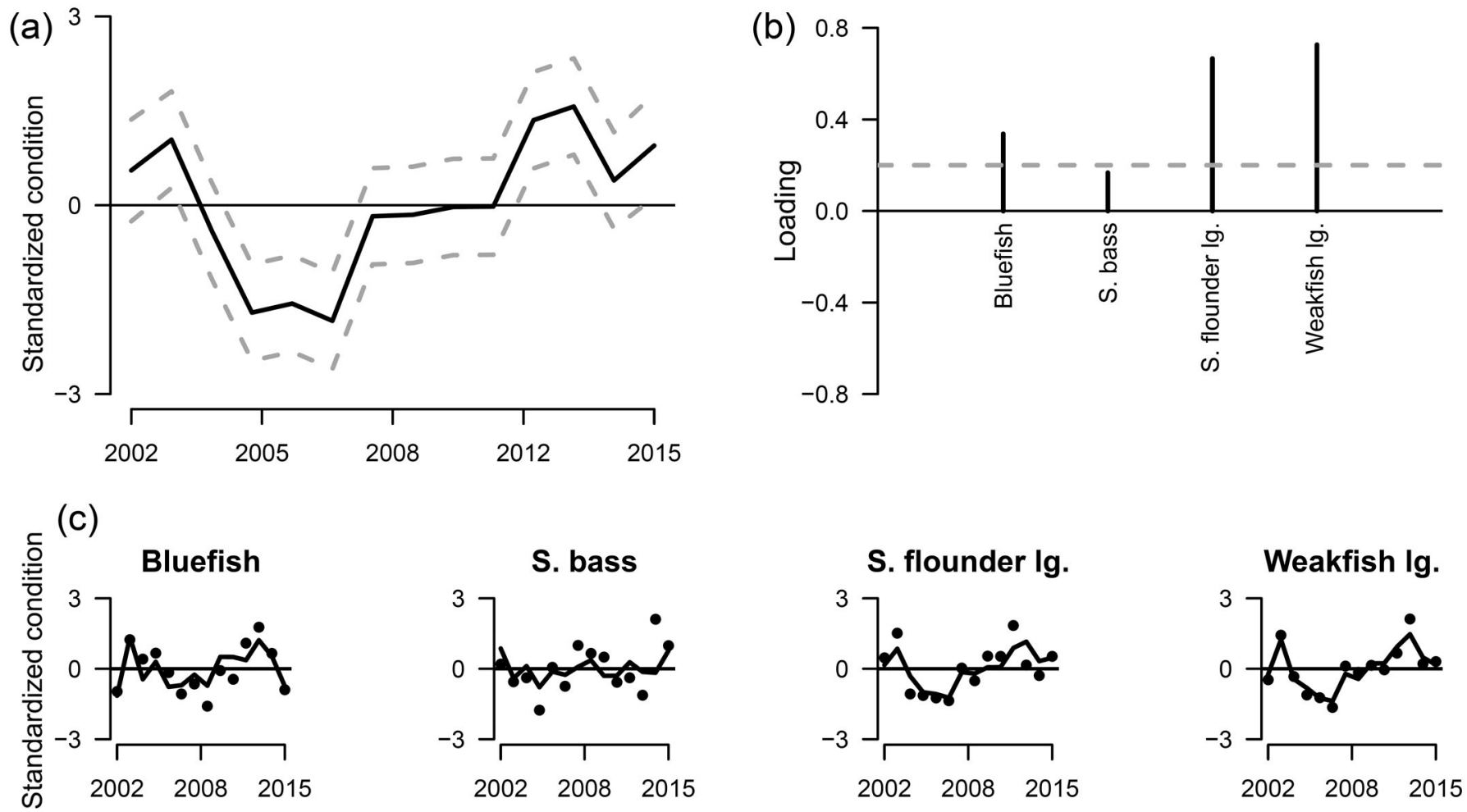

Fig. 6. (a) Estimated common trend (solid line) and 95\% CI (dashed lines) generated from dynamic factor analysis (DFA) using estimated annual mean condition values derived from linear mixed effect models for 4 piscivores (PISC) inhabiting Chesapeake Bay. (b) Factor loadings for each species or size-class; loadings greater than 0.2 (horizontal dashed line) identify timeseries of condition that had a relatively strong influence on the common trend. (c) Fits to the condition time-series for each species or size-class included in the PISC DFA. See Table 1 for full species names

cance was evident for striped bass (upper confidence limit [UCL]: 0.06) and large weakfish (LCL: -0.01 ; Table S4). Comparatively, there was no empirical support for models including bay anchovy relative abundance as a covariate.

The selected DFA model for the ZOOP group was the same as that for the ALL group except that both spring $\mathrm{chl} a$ and bottom temperature were included as covariates (Table S3). This model yielded only the second lowest AICc but a substantially lower Mean Fit value. The estimated common trend was generally similar to those of the other groups across most of the time-series, although a sharp decrease was estimated over the final 3 yr (Fig. $7 \mathrm{a}$ ). The overall magnitude of the fluctuations in condition for the ZOOP group was also less than that of the other groups, particularly during the low period of the mid-2000s. Factor loadings were all positive, large in magnitude, and statistically significant (Fig. 7b). All fits to the condition time-series were good, as evidenced by fairly small FitRatios (range: 0.22-0.35; Fig. 7c). Statistical significance of the estimated coefficients for the spring chl a covariate was only detected for alewife, although directionality was mixed with negative effects esti- mated for alewife and small summer flounder, and positive effects estimated for the others (Table S4). The estimated coefficients for the bottom temperature covariate were negative for all species/size-classes except northern searobin, and statistical significance was estimated for alewife and small summer flounder (Table S4).

\section{DISCUSSION}

Our goal was to quantify condition of key species representing an array of life history modes within the bay ecosystem and to describe patterns in condition indices at both the species-specific and community levels. Fine-scale spatial and temporal analyses showed both commonalities and variation across species that are likely related to biological and ecological similarity. However, multispecies annual trends in condition were coherent across a wide range of species, revealing synchronous responses to estuarine conditions at the community level.

It is acknowledged that Fulton's $k$ is a surrogate metric of physiological status and relationships among 

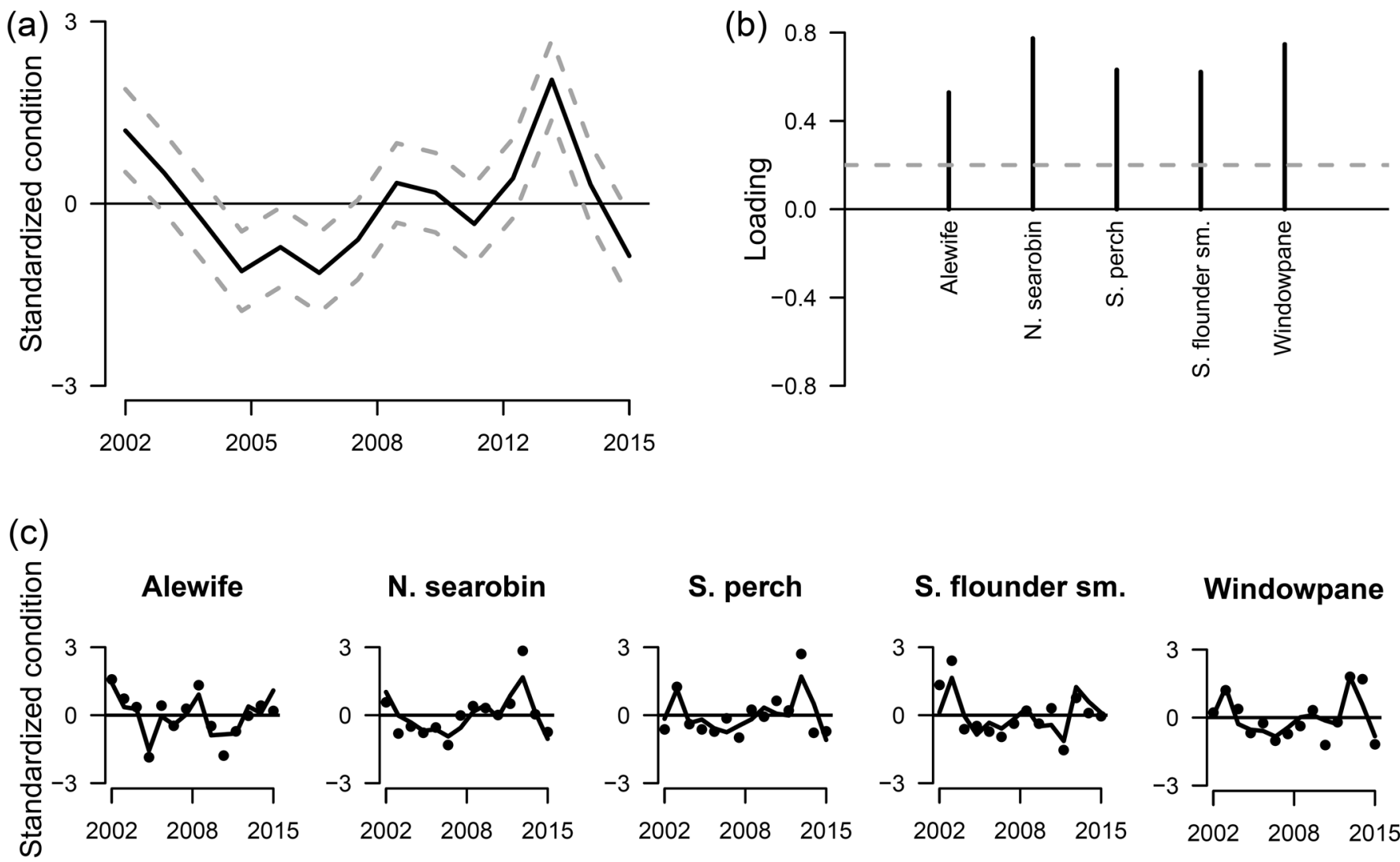

S. flounder sm.

Windowpane

Fig. 7. As in Fig. 6 but for 5 zooplanktivores (ZOOP) inhabiting Chesapeake Bay

morphometric indices and more direct biochemical measures of condition are not always readily apparent (McPherson et al. 2011, Brosset et al. 2015b). However, at present, direct biochemical measures of condition are unavailable for the life stages of the species in this study and we note that validation of Fulton's $k$ using more direct measures of fish condition for Chesapeake Bay fishes represents an important area of future research.

\section{Fine-scale patterns in condition}

For the 16 fish species evaluated, seasonal patterns in condition from spring through fall consistently decreased, increased, or displayed a somewhat parabolic trend characterized by mid-season minima. Intra-annual variation in trophic interactions represents a potentially straightforward explanation for these patterns, yet the diets of most fishes in the bay are generally consistent across seasons (Buchheister \& Latour 2015). Of the 5 species that exhibited seasonal declines in condition (alewife, kingfishes, silver perch, white perch, and windowpane flounder), peak spawning occurs during spring and early summer
(Murdy et al. 1997), which may support high earlyyear condition due to increased gonadal development, and reduced condition following spawning. Additionally, the Chesapeake Bay lies near the southern extent of the range for alewife, white perch, and windowpane flounder such that favorable earlyseason environmental conditions may support condition maxima that then decline due to metabolic stress associated with elevated temperatures (SchmidtNielsen 1997) during summer and early fall.

Three of the fishes showing the most pronounced seasonal increases in condition (Atlantic croaker, scup, and spot) are warm-water animals that spawn on the continental shelf during late fall and early winter (Murdy et al. 1997). Gonad development in preparation for fall spawning likely contributes to seasonal increases in condition, along with these species being better suited to physiologically adjust to higher summer and early fall bay temperatures. All scup analyzed in this study were immature juveniles likely maximizing foraging opportunities and growth throughout summer and early fall in preparation for migration to offshore overwintering grounds located at the edge of the continental shelf (Murdy et al. 1997). 
For species displaying approximately parabolic trends in seasonal condition, most spawn in the bay during mid-summer (northern puffer, northern searobin, hogchoker, and weakfish; Murdy et al. 1997). Therefore, relative changes due to gonadal development are not likely driving trends in condition for these species, and the mid-summer minima may be caused by stress responses to elevated temperature. Concurrent with high temperatures, species biodiversity and total abundance in the bay peaks during late summer (Buchheister et al. 2013, Lefcheck et al. 2014), and competitive interactions among species for forage resources presumably increase as well (Hixon \& Jones 2005). Also, hypoxic water in the deep channel of the bay mainstem during summer alters available habitat (Breitburg 2002, Craig 2012), which may exacerbate already challenging ecological conditions for several species.

Except for kingfishes and windowpane flounder, condition increased spatially with distance from a population's 'source' in the bay. In this context, the bay mouth is the 'source' for Atlantic croaker, bluefish, silver perch, spot, and summer flounder, since these species overwinter on the continental shelf and enter the bay in late spring/early summer (Murdy et al. 1997). Condition for these species increased along the south-to-north bay gradient. Within the bay mainstem, the 'source' area for gizzard shad and white perch is the northerly lower salinity zone (Jenkins \& Burkhead 1994, Kraus \& Secor 2005), and condition for these species also peaked in mid-bay. Functionally, the spatial region covariate is a proxy for salinity, which has been shown to be a dominant structuring factor in estuaries (Odum 1988, Wagner \& Austin 1999). Spatial patterns in condition could therefore be due to (1) lower resource competition, since pelagic and benthic fish biomass and diversity is lowest in the mesohaline bay (Jung \& Houde 2003, Buchheister et al. 2013); (2) migratory limitations, since greater energy reserves are needed to migrate longer distances; or (3) lower osmoregulatory costs, since euryhaline species can have lower resting metabolic rates in mesohaline regions of estuaries (Hettler 1976, Moser \& Hettler 1989). In all cases, the benefits of inhabiting the mid-bay must outweigh hypoxiainduced benthic productivity losses (Hagy et al. 2004, Kemp et al. 2005) and aforementioned habitat displacement effects (Breitburg 2002, Craig 2012).

Ontogenetic changes in condition are likely related to an increase in the breadth of prey types available to older animals (Scharf et al. 2000) and improved visual acuity (Kotrschal et al. 1990, Wahl et al. 1993). These advantages yield greater feeding success for older individuals, which translates into higher energy reserves and elevated condition (Lambert \& Dutil 1997). Greater energy reserves are also associated with improved survival to older ages, so young individuals of lower condition could be experiencing higher relative mortality. Changes in growth associated with maturation and gonad development will certainly influence ontogenetic patterns in condition, and they also likely explained the slightly higher estimated condition for females over males seen in the present study.

\section{Broad-scale patterns in condition}

Annual trends in condition exhibited by fishes in Chesapeake Bay showed remarkable coherence. For the ALL group, the emergence of a single common trend with strong positive loadings for all species analyzed suggests that factors influencing the suitability of the ecosystem, as measured by condition, act at the community level. The findings of this study suggest that the variation in fine-scale spatiotemporal utilization of the bay, as reflected by speciesspecific patterns in condition, is balanced by the likelihood of achieving longer-term benefits set by broad-scale bay ecosystem characteristics. In the context of ecosystem-based management for Chesapeake Bay, such insight is vital to proper interpretation of ecosystem indicators like fish condition. And although this study does not isolate the specific mechanisms responsible for the estimated patterns in condition, results can guide process-oriented studies focused more directly on ecosystem functioning in the bay.

Neither the AMO nor NAO were identified as significant predictors of condition for the ALL group (Table S3) despite documented influence of these and other broad-scale climate variables on fish stocks in several ecosystems (Roessig et al. 2004, Dulvy et al. 2008, Nye et al. 2009, Hollowed et al. 2013). This lack of a relationship between climatic indices and fish condition trends in Chesapeake Bay may be due to life history diversity among the species we analyzed and potential heterogeneous impacts of climate effects across those life history gradients. Alternatively, the AMO and NAO may exert influence on localized environmental and water quality parameters that more directly mediate fish condition, thus precluding identification of a strong relationship. The AMO and our chl a time-series were positively correlated (Pearson correlation, $\mathrm{r}=0.55$, $\mathrm{p}<0.05$ ), which provides some evidence of this potential sec- 
ondary effect. Also, the relatively abbreviated timeseries in this study likely limited detection of climate effects that presumably operate over much longer time scales (Perry et al. 2005). Unfortunately, we were unable to investigate possible top-down controls on condition such as density dependence due to a lack of independent measures of species or guild relative abundance derived from either harvest landings, since not all species support fisheries, or fishery-independent survey indices. Regarding the latter, the ChesMMAP survey data could be analyzed to provide species-specific or aggregated abundance indices; however, doing so implies that individuals from either all or a portion of each survey catch would contribute information to the dependent variable (the length, weight, sex, and age [when possible] information underpinning estimates of Fulton's $k$ ) and the explanatory covariate (indices of relative abundance). We viewed such an approach as lacking the appropriate independence for sound statistical inference.

The statistically significant positive effect of spring chl $a$ on annual condition of bluefish, kingfishes, silver perch, windowpane flounder, and-to an extent-weakfish, along with the negative effect on alewife and striped bass in the ALL group signaled a bottom-up effect on fish condition. High levels of primary productivity in the bay support relatively large secondary production of zooplankters such as mysid shrimp Neomysis spp. and crustacean communities, as the pelagic productivity is subsequently incorporated into the benthos (Baird \& Ulanowicz 1989, Diaz \& Schaffner 1990, Jumars 2007). This secondary production yields an increase in forage resources, which likely supports higher annual condition for those taxa with a positive estimated chl $a$ effect. The potential for moderate levels of nutrient enrichment and subsequent increases in primary production (i.e. eutrophication) to enhance fish production has been noted for several lacustrine, estuarine, and coastal ecosystems (Downing et al. 1990, Nixon \& Buckley 2002, Breitburg et al. 2009). Conversely, the negative effects estimated for alewife and striped bass may be associated with density-dependent early life history processes. Both species are anadromous, and recruitment success for each appears somewhat synchronous (Wood \& Austin 2009) and potentially driven by factors that also yield high primary productivity. For example, increased freshwater inflow to the bay has been linked to strong year classes of striped bass (Martino \& Houde 2010), and high freshwater inputs also enhance nutrient levels that underpin primary production. As such, the costs of intra-specific com- petition to maintain high year-class strength during the residence time in the bay may outweigh the benefits of increased food resources.

Also, striped bass in Chesapeake Bay are experiencing high prevalence of the bacterial disease mycobacteriosis (Gauthier et al. 2008), with evidence of altered growth patterns and condition between disease-positive and -negative fish (Latour et al. 2012). Direct hypotheses of disease transmission in the field remain difficult to test, although some etiologic agents are ubiquitously distributed in water of the bay mainstem (Gauthier et al. 2010) and correlated to eutrophic conditions (Jacobs et al. 2009). Therefore, elevated chl a may suppress striped bass condition through complex dynamics involving environmental effects on disease pathobiology. Lastly and with regard to alewife, the majority of fish sampled in this study were post young-of-year collected in March during the spawning season (Murdy et al. 1997), and as such, this species may not be well positioned to benefit from the spring phytoplankton bloom, since associated secondary production occurs after most of these fish have returned to sea.

The primary motivation for the guild analyses was to investigate potential similarities or differences among temporal patterns and drivers of condition in trophically defined components of the Chesapeake Bay fish assemblage. The common trend exhibited by the BENTH group mimicked that of the finfish community as a whole, suggesting no considerable divergence from overall community response. The noted moderate empirical support for the model including the polychaete density covariate strengthens the evidence for bottom-up effects on condition, albeit through a more direct pathway than chl a. However, it is important to note that the benthic fish community in the mainstem Chesapeake Bay has experienced appreciable declines since 2007, mainly driven by decreases in the abundance of Atlantic croaker and spot (Buchheister et al. 2013). The causes of these declines remain unknown, and recent increasing trends in mean annual condition of the BENTH group may be reflective of density-dependent controls.

The common trend for the PISC group also reflected that of the ALL fishes group, with chl a again being an empirically supported covariate. This result suggests a linkage between primary production and condition in the top predatory teleost fishes inhabiting the bay. Likely central to this linkage are the zooplankters mysid shrimp and bay anchovy because of their roles as key prey taxa of the PISC group (Buchheister \& Latour 2015). Unfortunately, 
data on mysid shrimp density in Chesapeake Bay are lacking, so direct investigation of this hypothesis is not possible. Bay anchovy would presumably benefit from increased primary production, yet the chl $a$ and bay anchovy relative abundance time-series were not significantly correlated (Pearson correlation, $\mathrm{r}=$ $0.23, p=0.42$ ), and there was no empirical support for DFA models that included the bay anchovy covariate. Sampling by the VIMS Juvenile Fish and Blue Crab Trawl Survey is restricted to the Virginia portion of Chesapeake Bay, so it is possible that the relative abundance pattern does not reflect that of the full bay mainstem. In addition to food availability, numerous physical (currents, temperature, salinity, DO) and behavioral (vertical migration) factors shape bay anchovy recruitment dynamics (North \& Houde 2004), which could explain the lack of coupling among chl $a$ and relative abundance. It should also be noted that members of the PISC group feed on a number of prey types in addition to bay anchovy, both pelagic and benthic (Buchheister \& Latour 2015), and that these species all likely benefit from increased primary production. Therefore, patterns in condition of the PISC group are the integrative result of effects from a diverse array of prey sources as opposed to a single prey taxon.

Although the common trend of the ZOOP group generally followed that of the ALL group, the former showed a relatively steep decline in condition in recent years. The covariates chl $a$ and bottom temperature were empirically supported, and both showed declines in recent years. A primary prey type of the taxa in the ZOOP group is mysid shrimp, and their population dynamics presumably tightly follow fluctuations in primary production (Buchheister \& Latour 2015). The positive effect of chl a on the condition of northern searobin, silver perch, and windowpane flounder provides further evidence for bottom-up control of production in this system. As noted previously, the density-dependent processes in early life history stages during years of high freshwater inflow coupled with the mismatch in the timing of the spring phytoplankton bloom and the residence period of adult alewife in the bay may yield the observed negative effect of $\mathrm{chl} a$ on alewife mean condition. Similarly, reductions in juvenile summer flounder growth have been observed in environments characterized by lower salinities (Nys et al. 2015). The same study also found impaired growth of small summer flounder at elevated temperatures, which is consistent with the negative effect of temperature on condition given by the DFA model. The relationships between temperature and condition for the remaining species of the ZOOP group are congruent with the cold or warm-water life history strategies of these species. While temperature exerted a negative effect on the condition of silver perch (a warm-water species), the effect was small and nonsignificant.

Ecosystem-based management for Chesapeake Bay requires the development of a suite of metrics designed to yield information on ecosystem status and, in particular, the suitability of the ecosystem from the perspective of living resources (Pikitch et al. 2004, Link 2010). Fish condition is often considered a candidate metric, and we have demonstrated that even though individual species exhibit fine-scale spatiotemporal variation in condition, annual trends are relatively coherent at the community level. Further, by relating these trends to ecosystem covariates, we have identified useful indicators of condition at scales appropriate to support ecosystem modeling and management efforts for the bay.

Acknowledgements. The authors wish to acknowledge field and sample processing efforts of past and present members of the Multispecies Research Group at the Virginia Institute of Marine Science. Captains L.D. Ward, J. Olney Jr., and K. Mayer and past vessel crew members deserve thanks for their contributions to field operations. C. Peterson provided thoughtful insights regarding statistical analyses. Comments provided by 3 anonymous reviewers helped improve this manuscript. Funding was provided by the NOAA Chesapeake Bay Office, the Virginia Environmental Endowment, the US Fish and Wildlife Service, and the Virginia Marine Resources Commission. This is contribution no. 3660 of the Virginia Institute of Marine Science, College of William \& Mary.

\section{LITERATURE CITED}

Able KW, Fahay MP (2010) Ecology of estuarine fishes: temperate waters of the Western North Atlantic. Johns Hopkins University Press, Baltimore, MD

Akaike H (1973) Information theory as an extension of the maximum likelihood principle. In: Petrov BN, Csaki F (eds) Second international symposium on information theory. Akademiai Kiado, Budapest, p 267-281

Arkema KK, Abramson SC, Dewsbury BM (2006) Marine ecosystem based management: from characterization to implementation. Front Ecol Environ 4:525-532

Baird D, Ulanowicz RE (1989) The seasonal dynamics of the Chesapeake Bay ecosystem. Ecol Monogr 59:329-364

Beck MW, Heck KL Jr, Able KW, Childers DL and others (2001) The identification, conservation, and management of estuarine and marine nurseries for fish and invertebrates: a better understanding of the habitats that serve as nurseries for marine species and the factors that create site-specific variability in nursery quality will improve conservation and management of these areas. Bioscience 51:633-641

Breitburg D (2002) Effects of hypoxia, and the balance 
between hypoxia and enrichment, on coastal fishes and fisheries. Estuar Coasts 25:767-781

Breitburg DL, Craig JK, Fulford RS, Rose KA and others (2009) Nutrient enrichment and fisheries exploitation: interactive effects on estuarine living resources and their management. Hydrobiologia 629:31-47

*Bosset P, Ménard F, Fromentin JM, Bonhommeau S and others (2015a) Influence of environmental variability and age on the body condition of small pelagic fish in the Gulf of Lions. Mar Ecol Prog Ser 529:219-231

Brosset P, Fromentin JM, Ménard F, Pernet F and others (2015b) Measurement and analysis of small pelagic fish condition: a suitable method for rapid evaluation in the field. J Exp Mar Biol Ecol 462:90-97

Browman HI, Stergiou KI (2004) Perspectives on ecosystembased approaches to the management of marine resources. Mar Ecol Prog Ser 274:269-303

Brush GS (1989) Rates and patterns of estuarine sediment accumulation. Limnol Oceanogr 34:1235-1246

Buchheister A, Latour RJ (2015) Diets and trophic guild structure of a diverse fish assemblage in Chesapeake Bay, USA. J Fish Biol 86:967-992

Buchheister A, Bonzek CF, Gartland J, Latour RJ (2013) Patterns and drivers of the demersal fish community of Chesapeake Bay. Mar Ecol Prog Ser 481:161-180

Burnham KP, Anderson DR (2002) Model selection and multimodel inference: a practical information-theoretic approach, 2nd edn. Springer, New York, NY

Craig JK (2012) Aggregation on the edge: effects of hypoxia avoidance on the spatial distribution of brown shrimp and demersal fishes in the Northern Gulf of Mexico. Mar Ecol Prog Ser 445:75-95

* Curtin R, Prellezo R (2010) Understanding marine ecosystem based management: a literature review. Mar Policy 34: 821-830

Day JW, Hall CAS, Kemp WM, Yàñez-Arancibia A (1989) Estuarine ecology. John Wiley \& Sons, New York, NY

Diaz RJ, Schaffner LC (1990) The functional role of estuarine benthos. In: Haire M, Krome EC (eds) Perspectives on the Chesapeake Bay. Chesapeake Research Consortium, Gloucester Point, VA, p 25-56

Downing JA, Plante C, Lalonde S (1990) Fish production correlated with primary productivity, not the morphoedaphic index. Can J Fish Aquat Sci 47:1929-1936

Dulvy NK, Rogers SI, Jennings S, Stelzenmüller V, Dye SR, Skjoldal HR (2008) Climate change and deepening of the North Sea fish assemblage: a biotic indicator of warming seas. J Appl Ecol 45:1029-1039

Fulton, TW (1904) The rate of growth in fishes. In: Twentysecond Annual Report of the Fishery Board for Scotland. Being for the Year 1903. Part III: Scientific Investigations. Printed for His Majesty's Stationary Office by James Hedderwick \& Sons, Glasgow, p 141-241

Gauthier DT, Latour RJ, Heisey DM, Bonzek CF, Gartland J, Burge EJ, Vogelbein WK (2008) Mycobacteriosisassociated mortality in wild striped bass (Morone saxatilis) from Chesapeake Bay, USA. Ecol Appl 18: 1718-1727

Gauthier DT, Reece KS, Xiao J, Rhodes MW and others (2010) Quantitative PCR assay for Mycobacterium pseudoshottsii and Mycobacterium shottsii and application to environmental samples and fishes from the Chesapeake Bay. Appl Environ Microbiol 76:6171-6179

Hagy JD, Boynton WR, Keefe CW, Wood KV (2004) Hypoxia in Chesapeake Bay, 1950-2001: long-term change in relation to nutrient loading and river flow. Estuaries 27: $634-658$
Hettler WF (1976) Influence of temperature and salinity on routine metabolic rate and growth of young Atlantic menhaden. J Fish Biol 8:55-65

*Hixon MA, Jones GP (2005) Competition, predation, and density-dependent mortality in demersal marine fishes. Ecology 86:2847-2859

Hollowed AB, Barange M, Beamish RJ, Brander $\mathrm{K}$ and others (2013) Projected impacts of climate change on marine fish and fisheries. ICES J Mar Sci 70:1023-1037

Holmes EE, Ward EJ, Scheuerell MD (2014) Analysis of multivariate time-series using the MARSS package version 3.0. NOAA Fisheries, Northwest Fisheries Science Center, Seattle, WA

Hooper DU, Chapin FS, Ewel JJ, Hector A and others (2005) Effects of biodiversity on ecosystem functioning: a consensus of current knowledge. Ecol Monogr 75:3-35

Jackson JB, Kirby MX, Berger WH, Bjorndal KA and others (2001) Historical overfishing and the recent collapse of coastal ecosystems. Science 293:629-637

Jacobs J, Rhodes M, Sturgis B, Wood B (2009) Influence of environmental gradients on the abundance and distribution of Mycobacterium spp. in a coastal lagoon estuary. Appl Environ Microbiol 75:7378-7384

Jakob EM, Marshall SD, Uetz GW (1996) Estimating fitness: a comparison of body condition indices. Oikos 77:61-67

Jenkins RE, Burkhead NM (1994) Freshwater fishes of Virginia. American Fisheries Society, Bethesda, MD

Jumars PA (2007) Habitat coupling by mid-latitude, subtidal, marine mysids: import-subsidized omnivores. Oceanogr Mar Biol Annu Rev 45:89-138

* Jung S, Houde ED (2003) Spatial and temporal variabilities of pelagic fish community structure and distribution in Chesapeake Bay, USA. Estuar Coast Shelf Sci 58: 335-351

Kemp WM, Boynton WR, Adolf JE, Boesch DF and others (2005) Eutrophication of Chesapeake Bay: historical trends and ecological interactions. Mar Ecol Prog Ser 303:1-29

Kotrschal K, Adam H, Brandstätter R, Junger H, Zaunreiter M, Goldschmid A (1990) Larval size constraints determine directional ontogenetic shifts in the visual system of teleosts. J Zoological Syst Evol Res 28:166-182

Kraus RT, Secor DH (2005) Application of the nursery-role hypothesis to an estuarine fish. Mar Ecol Prog Ser 291: 301-305

Kambert Y, Dutil JD (1997) Can simple condition indices be used to monitor and quantify seasonal changes in the energy reserves of cod (Gadus morhua)? Can J Fish Aquat Sci 54:104-112

KLatour RJ, Gauthier DT, Gartland J, Bonzek CF, McNamee KA, Vogelbein WK (2012) Impacts of mycobacteriosis on the growth of striped bass (Morone saxatilis) in Chesapeake Bay. Can J Fish Aquat Sci 69:247-258

* Le Cren ED (1951) The length-weight relationship and seasonal cycle in gonad weight and condition in the perch (Perca fluviatilis). J Anim Ecol 20:201-219

* Lefcheck JS, Buchheister A, Laumann KM, Stratton MA and others (2014) Dimensions of biodiversity in Chesapeake Bay demersal fishes: patterns and drivers through space and time. Ecosphere 5:art14

Link J (2010) Ecosystem-based fisheries management: confronting tradeoffs. Cambridge University Press, Cambridge

* Lloret J, de Sola LG, Souplet A, Galzin R (2002) Effects of large-scale habitat variability on condition of demersal exploited fish in the north-western Mediterranean. ICES J Mar Sci 59:1215-1227

* Lotze HK, Lenihan HS, Bourque BJ, Bradbury RH and others 
(2006) Depletion, degradation, and recovery potential of estuaries and coastal seas. Science 312:1806-1809

Marshak AR, Link JS, Shuford R, Monaco ME and others (2017) International perceptions of an integrated, multisectoral, ecosystem approach to management. ICES J Mar Sci 74:414-420

Martino EJ, Houde ED (2010) Recruitment of striped bass in Chesapeake Bay: spatial and temporal environmental variability and availability of zooplankton prey. Mar Ecol Prog Ser 409:213-228

* McPherson LR, Slotte A, Kvamme C, Meier S, Marshall CT (2011) Inconsistencies in measurement of fish condition: a comparison of four indices of reserves for Atlantic herring (Clupea harengus). ICES J Mar Sci 68:52-60

Moser ML, Hettler WF (1989) Routine metabolism of juvenile spot, Leiostomus xanthurus (Lacépède), as a function of temperature, salinity, and weight. J Fish Biol 35: 703-707

Murdy EO, Birdsong RS, Musick JA (1997) Fishes of Chesapeake Bay. Smithsonian Institution Press, Washington, DC

Najjar RG, Pyke CR, Adams MB, Breitburg D and others (2010) Potential climate-change impacts on the Chesapeake Bay. Estuar Coast Shelf Sci 86:1-20

Nakagawa S, Schielzeth H (2013) A general and simple method for obtaining $\mathrm{R}^{2}$ from generalized linear mixedeffects models. Methods Ecol Evol 4:133-142

Nixon SW (1995) Coastal marine eutrophication: a definition, social causes, and future concerns. Ophelia 41: 199-219

* Nixon SW, Buckley BA (2002) 'A strikingly rich zone'nutrient enrichment and secondary production in coastal marine ecosystems. Estuaries 25:782-796

North EW, Houde ED (2004) Distribution and transport of bay anchovy (Anchoa mitchilli) eggs and larvae in Chesapeake Bay. Estuar Coast Shelf Sci 60:409-429

Nye JA, Link JS, Hare JA, Overholtz WJ (2009) Changing spatial distribution of fish stocks in relation to climate and population size on the Northeast United States continental shelf. Mar Ecol Prog Ser 393:111-129

Nys LN, Fabrizio MC, Tuckey TD (2015) Multi-decadal variation in size of juvenile summer flounder (Paralichthys dentatus) in Chesapeake Bay. J Sea Res 103:50-58

Odum WE (1988) Comparative ecology of tidal freshwater and salt marshes. Annu Rev Ecol Syst 19:147-176

*Parrish RH, Mallicoate DL (1995) Variation in the condition factors of California pelagic fishes and associated environmental factors. Fish Oceanogr 4:171-190

* Perry AL, Low PJ, Ellis JR, Reynolds JD (2005) Climate change and distribution shifts in marine fishes. Science 308:1912-1915

Pikitch EK, Santora C, Babcock EA, Bakun A and others (2004) Ecosystem-based fishery management. Science 305:346-347

Pinto R, de Jonge VN, Marques JC (2014) Linking biodiversity indicators, ecosystem functioning, provision of services and human well-being in estuarine systems: application of a conceptual framework. Ecol Indic 36: 644-655

Pritchard DW (1967) Observations of circulation in coastal plain estuaries. In: Lauff GH (ed) Estuaries. American Association for the Advancement of Science, Washington, DC, p 37-44

$\mathrm{R}$ Core Team (2016) R: a language and environment for statistical computing. R Foundation for Statistical Computing, Vienna. www.R-project.org/
Rätz HJ, Lloret J (2003) Variation in fish condition between Atlantic cod (Gadus morhua) stocks, the effect on their productivity and management implications. Fish Res 60: 369-380

Kichards RA, Rago PJ (1999) A case history of effective fishery management: Chesapeake Bay striped bass. N Am J Fish Manage 19:356-375

Ricker WE (1975) Computation and interpretation of biological statistics of fish populations. Bull Fish Res Board Can 191, Environment Canada, Fisheries and Marine Service, Ottawa

* Roessig JM, Woodley CM, Cech JJ, Hansen LJ (2004) Effects of global climate change on marine and estuarine fishes and fisheries. Rev Fish Biol Fish 14:251-275

* Rothschild BJ, Ault JS, Goulletquer P, Heral M (1994) Decline of the Chesapeake Bay oyster population: a century of habitat destruction and overfishing. Mar Ecol Prog Ser 111:29-39

Scharf FS, Juanes F, Rountree RA (2000) Predator size-prey size relationships of marine fish predators: interspecific variation and effects of ontogeny and body size on trophic-niche breadth. Mar Ecol Prog Ser 208:229-248

Schmidt-Nielsen K (1997) Animal physiology: adaptation and environment. Cambridge University Press, Cambridge

Searle SR, Speed FM, Milliken GA (1980) Population marginal means in the linear model: an alternative to least squares means. Am Stat 34:216-221

* Stachura MM, Mantua NJ, Scheuerell MD (2014) Oceanographic influences on patterns in North Pacific salmon abundance. Can J Fish Aquat Sci 71:226-235

* Stevenson RD, Woods WA (2006) Condition indices for conservation: new uses for evolving tools. Integr Comp Biol 46:1169-1190

Vasconcelos RP, Reis-Santos P, Fonseca V, Ruano M, Tanner S, Costa MJ, Cabral HN (2009) Juvenile fish condition in estuarine nurseries along the Portuguese coast. Estuar Coast Shelf Sci 82:128-138

*Vila Gispert A, Moreno Amich R (2001) Fish condition analysis by a weighted least squares procedure: testing geographical differences of an endangered Iberian cyprinodontid. J Fish Biol 58:1658-1666

*Wagner CM, Austin HM (1999) Correspondence between environmental gradients and summer littoral fish assemblages in low salinity reaches of the Chesapeake Bay, USA. Mar Ecol Prog Ser 177:197-212

* Wahl CM, Mills EL, McFarland WN, DeGisi JS (1993) Ontogenetic changes in prey selection and visual acuity of the yellow perch, Perca flavescens. Can J Fish Aquat Sci 50: 743-749

WWilberg MJ, Livings ME, Barkman JS, Morris BT, Robinson JM (2011) Overfishing, disease, habitat loss, and potential extirpation of oysters in upper Chesapeake Bay. Mar Ecol Prog Ser 436:131-144

WWood RJ, Austin HM (2009) Synchronous multidecadal fish recruitment patterns in Chesapeake Bay, USA. Can J Fish Aquat Sci 66:496-508

* Zuur AF, Fryer RJ, Jolliffe IT, Dekker R, Beukema JJ (2003a) Estimating common trends in multivariate time series using dynamic factor analysis. Environmetrics 14:665-685

Zuur AF, Tuck ID, Bailey N (2003b) Dynamic factor analysis to estimate common trends in fisheries time series. Can J Fish Aquat Sci 60:542-552

Zuur AF, Ieno EN, Walker NJ, Saveliev AA, Smith GM (2009) Mixed effects models and extensions in ecology with R. Springer, New York, NY 